\title{
A case of basal cell carcinoma secondary to nevus sebaceous
}

\author{
Nursel Dilek, Recep Bedir, Derya Yüksel, Arzu Ataseven
}

\begin{abstract}
Introduction: Nevus sebaceous is a congenital hamartomatous lesion that usually appears on the scalp and neck. With the advance of age, benign and malignant tumor changes on nevus sebaceous lesions may occur, these tumors are usually benign. Malignant transformation is very rare on the sebaceous nevus and the basal cell carcinoma is the most common. Case Report: A 50-year-old female patient was admitted to our clinic with a $5 \times 3 \mathrm{~cm}$ sized a verrucous erythematous plaque on the left parietal region of head. Total surgical excision was performed and histopathological examination of the sample revealed a basal cell carcinoma developed on ground of nevus sebaceous. Conclusion: To highlight importance of this rare malign development, a case of basal cell carcinoma on the ground of nevus sebaceous is presented.
\end{abstract}

Keywords: Nevus sebaceous, Tumor, Basal cell carcinoma

Nursel Dilek ${ }^{1}$, Recep Bedir², Derya Yüksel ${ }^{1}$, Arzu Ataseven $^{3}$ Affiliations: 'Dermatology Department of Recep Tayyip Erdoğan University Medical Faculty Hospital, Rize, Turkey; ${ }^{2}$ Pathology Department of RecepTayyipErdoğan University Medical Faculty Hospital, Rize, Turkey; ${ }^{3}$ Dermatology Department of Konya Research and Education Hospital, Konya, Turkey.

Corresponding Author: Nursel Dilek, Dermatology Department of RecepTayyipErdoğan University Medical Faculty Hospital, Rize, Turkey, Postal Code: 53000; Phone: 0090-464-2130491; Email: nur.dilek@hotmail.com

Received: 29 July 2013

Accepted: 02 September 2013

Published: 01 April 2014

\section{How to cite this article}

Dilek N, Bedir R, Yüksel D, Ataseven A. A case of basal cell carcinoma secondary to nevus sebaceous. International Journal of Case Reports and Images 2014;5(4):277-280.

doi:10.5348/ijcri-201457-CR-10368

\section{INTRODUCTION}

Nevus sebaceous is a benign congenital hamartomatous lesion most commonly shows sebaceous malformation but different proportions of epithelial, follicular and apocrine malformation can be seen [1]. The lesions appear at birth as small swelling almost insensible and they can progressively begin to appear thickened and irregular borders at late childhood and adulthood. It usually appears on hairy skin and face but it also appears on the neck and less frequently on the body. The scalp lesions show alopecic features [2].

Nevus sebaceous presents $0.05-1 \%$ of outpatients applying to the dermatology clinic. Nevus sebaceous occurs with equal frequency in males and females. Nevus sebaceous are generally sporadic, lesions are thought to develop as a result of para dominant inheritance in cases of inherited nevus sebaceous $[1,3]$. About $14 \%$ of nevus sebaceous cases develop to malignancies in late childhood and adulthood period, most of the malignancies are benign [2, 4]. Benign tumors include syringocystadenoma papilliferum (5\%), trichoblastoma (4.5\%), trichilemmoma (2.5\%) and sebaceoma (2.1\%). Malign conversions, which are less than $1 \%$, includes basal cell carcinoma (BCC) and squamous cell carcinomas [4]. Malignant changes occurs in about $10-30 \%$ of the patients $40-70$ years of age $[5,6]$.

Several theories have been proposed for the proliferative changes in nevus sebaceous. Deletions in the patched gene has been determined in nevus sebaceous and it has been reported that this deletion causes the development of BCC and other tumoral structures by 
activation of patched-hedgehog signaling pathway, although this idea has not been supported by further studies [1].

Herein, a case of $\mathrm{BCC}$ on the ground of nevus sebaceous is presented with review of available literature.

\section{CASE REPORT}

A 50-year-old female patient was admitted to our clinic with alopecic lesion which present from birth in hairy skin, which was enlarged in the recent year and became a reddish stalked mass. She had no complaint apart from bleeding of the lesion while combing hair.

The patient had no self and family genetic background for cancer and routine laboratory findings were within normal limits (hemogram, biochemistry, whole blood). Dermatological examination revealed a $5 \times 3 \mathrm{~cm}$ sized a verrucous erythematous plaque on the left parietal region of head, on which there was $1 \times 1 \mathrm{~cm}$ erythema on the right upper corner. She had no similar lesions on other parts of the body. Total surgical excision was performed with preliminary diagnosis of syringocystadenoma papilliferum, trichoblastoma and BCC. We made an incision through the full three layers of the skin around the obvious area of the skin cancer. The specimen was removed and the edges of the wound were pulled together using plastic surgery techniques. Histopathological examination of the sample revealed a BCC (ulceration of epidermal surface, infiltrating basolateral cell islands to dermis, positive staining in basaloid cells with CD10) developed on ground of nevus sebaceous (Figures 1 and 2) and no tumor was detected within the surgical limits. The patient was referred to the plastic surgery department with suggestion of total excision of nevus sebaceous due to potential of new malignity progression. Another medical management was not given. The patient did not receive any radiotherapy.

\section{DISCUSSION}

Nevus sebaceous is a congenital hamartomatous malformation, also known as organoid nevus, first described in 1895 by Jadassohn, describes alterations of glands involving epithelial, pilar, sebaceous, eccrine and apocrine structures with various levels of follicular, sebaceous and apocrine differentiation $[1,7]$.

Nevus sebaceous presents as a solitary lesion, usually present at birth and it may develop in early childhood. Clinically, it appears as mild swelling, shiny velour plaque at birth and infancy. At puberty, by the effects of the androgen hormones the sebaceous glands maturates and became functioning resulting in the development of yellow, papillomatous-verrucous lesions $[8,9]$.

Arising of tumor from nevus sebaceous usually occurs at puberty or later stages. Most common benign tumors are syringocystadenoma papilliferum and

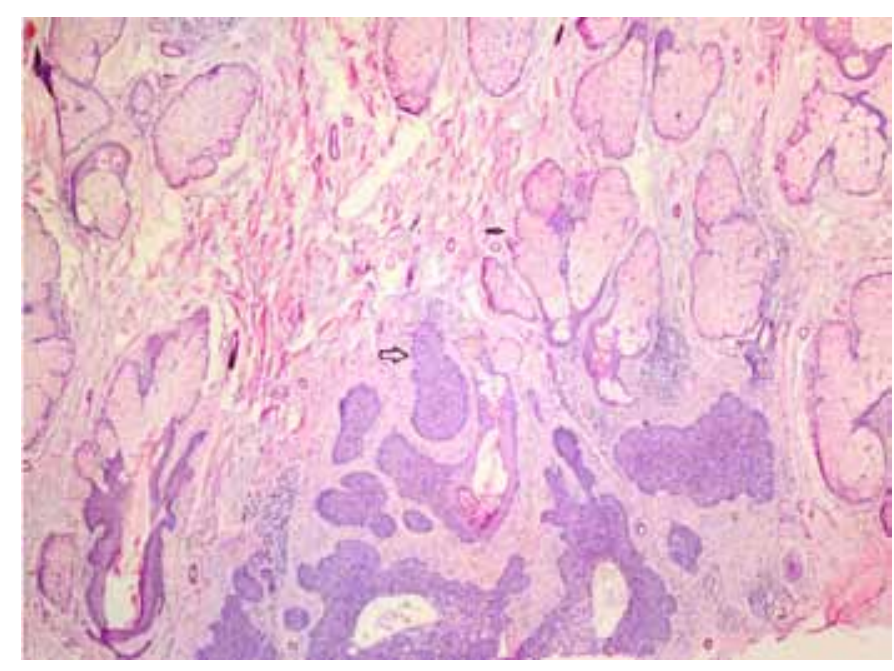

Figure 1: Basal cell carcinoma in the background of sebaceous nevus. Sebaceous glands (thin arrow), basal cell nests (thick arrow), (H\&E stain, X400).

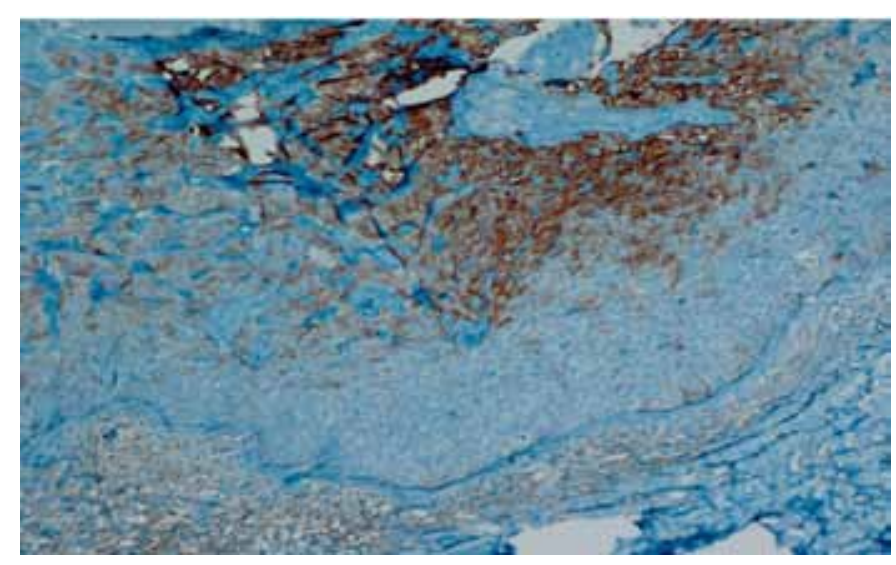

Figure 2: Strong positive staining in basaloid cells with CD10

trichoepithelioma and trichoblastoma. Less frequently occurring tumors includes leiomyoma, syringoma, spiradenoma, hidradenoma and keratoacanthoma $[5,10$, 11].

Malignant transformations on the ground of nevus sebaceous are very rare whereas BCC is the most common among these. Recent studies indicate that the rate of BCC development on the ground of nevus sebaceous is not $10 \%$ as suggested by previous studies but, in fact, it is less than $1 \%[2,4,5]$. Two retrospective studies involving 596 and 757 patients, those diagnosed as BCC were confused and they actually had trichoblastoma and therefore despite suppositional rate transformation of $\mathrm{BCC}$ on the ground of nevus sebaceous is much rarer $[5,10,12]$.

Basal Cell carcinoma cases especially the nodular type should be histopathologically differentiated from eccrine spiradenoma, nodular hidradenoma and trichoepithelioma or trichoblastoma like benign adnexal proliferations. Typical nodular BCCs with telangiectasia 
may be present as pearl appearance elevated nodules of ulceration or cysts. Histopathologically, large lobule basaloid cells with peripheral palisading nuclei may appear. The lobules may involve mucinous degenerations $[11,13]$.

Eccrine spiradenoma is well bordered intradermal nodule with no connection with epidermis. The tumor contains small cells with dark-colored nuclei and larger cells with light color nuclei. Mitosis and dyskeratosis is not common. Nodular hidradenoma has no connection with the epidermis and the rate of mitosis is low. It may differentiate towards the eccrine channel. This tumor may invade deeper than nodular BCC. Necrosis is not common, peripheral cell palisades and mucin deposits do not appear. Differentiating BCC from trichoepithelioma or trichoblastoma can be difficult. These tumors may contain focal calcifications. Small keratin cysts may be present. But basaloid cell proliferation is not typical and mucin formation is rare. Mitotic activity and apoptosis is decreased. Typically, these tumors presents with mild or moderate fibrosis formation around dermis. Stromal changes are more prominent compared to the normal dermis. The decomposition of stroma may be present. CD34 is positive or stroma of trichoblastoma while being negative for BCC. Focal positive staining of BCC with cytokeratin 7,8 , and even more staining with $\mathrm{CD} 10$ is important for differentiation of trichoblastoma or trichoepithelioma $[5,11,13]$. Additionally, the presence of ulceration in BCC is another important parameter in differentiation from trichoblastoma $[5,13]$.

Ulceration in surface epidermis and connection between the epidermis bazaliod islands were evident in our case. Immunohistochemical examination revealed CD10 and positive staining in the basaloid cells while no positive staining in the stromal cells.

Among to other malignant tumors arising from nevus sebaceous are apocrine carcinoma, squamous cell carcinoma and malignant eccrine poroma [10]. Patients with nevus sebaceous should closely be clinically followed and any changes suspicious of evoking tumor should be sampled for pathology. At early stage, total surgical excision remains a matter of debate. Some suggests early period prophylactic excision for prevention of malignant development while others find this unnecessary $[5,8]$.

\section{CONCLUSION}

In this article, a case of basal cell carcinoma on the ground of nevus sebaceous is presented with aim of highlighting the significance of this rare entity.

$* * * * * * * * *$

\section{Author Contributions}

Nursel Dilek - Substantial contributions to conception and design, Revising it critically for important intellectual content, Final approval of the version to be published Recep Bedir - Analysis and interpretation of data, Drafting the article, Revising it critically for important intellectual content, Final approval of the version to be published

Derya Yüksel - Analysis and interpretation of data, Drafting the article, Final approval of the version to be published

Arzu Ataseven - Analysis and interpretation of data, Revising it critically for important intellectual content, Final approval of the version to be published

\section{Guarantor}

The corresponding author is the guarantor of submission.

\section{Conflict of Interest}

Authors declare no conflict of interest.

\section{Copyright}

(C) Nursel Dilek et al. 2014; This article is distributed under the terms of Creative Commons attribution 3.0 License which permits unrestricted use, distribution and reproduction in any means provided the original authors and original publisher are properly credited. (Please see www.ijcasereportsandimages.com/copyright-policy.php for more information.)

\section{REFERENCES}

1. Seçkin D, Güleç AT, Bilezikçi B. DeriEkiTümörleri. Dermatoloji'de. Ed. Tüzün Y, Gürer MA, Serdaroğlu S, Oğuz O, Aksungur VL. 3. Baskı, Nobel Tip Kitabevleri, İstanbul, 2008: 1824-64.

2. McCalment TH. Adnexal neoplasms. In: Dermatology. Bolognia JL, Jorizzo JL, Rappini RP, eds. Spain, Mosby 2008: 1693-6.

3. Laino L, Steensel MA, Innocenzi D, Camplone G. Familial occurrence of nevus sebaceus of Jadassohn: another case of paradominant inheritance? Eur J Dermatol 2001; 11: 97-8.

4. Dalle S, Skowron F, Balme B, Perrot H. Apocrine carcinoma developed in nevus sebaceus of Jadassohn. Eur J Dermatol 2003; 13: 487-9.

5. Cribier B, Scrivener Y, Grosshans E. Tumors arising in nevus sebaceus: A study of 596 cases. J Am AcadDermatol 2000; 42: 263-8.

6. Miller CJ, Ioffreda MD, Billingsley EM. Sebaceous Carcinoma, Basal Cell Carcinoma, Trichoadenoma, Trichoblastoma, AndSyringocystadenomaPapilliferum Arising Within A Nevus Sebaceus. Dermatol Surg. 2004; 30(12): 1546-9.

7. Altaykan A, Ersoy-Evans S, Erkin G, Ozkaya O. Basal cell carcinoma arising in nevus sebaceous during childhood. PediatrDermatol 2008; 25(6): 619-9.

8. Baykal C, Buyukbabani N, Yazganoglu KD, Saglik E. Tumors associated with nevus sebaceous. J DtschDermatolGes. 2006; 4(1): 28-31.

9. Mehregan AH, Pinkus H. Life history of organoidnaevi. Special reference to naevus sebaceous of Jadassohn. Arch Dermatol 1965; 91: 574-88. 
10. Thomas VD, Swanson NA, Lee KK. Benign Epithelial Tumors, Hamartomas, and Hyperplasias. Fitzpatrick's Dermatology İnGeneral Medicine. WolffK, Goldsmith La, Katz SI, Gilchrest BA, Paller AS, Leffell DJ, Eds. Seventh Ed, The McGraw-Hili Companies Inc, New York, 2008: 1054-67.

11. Hurt MA, Kaddu S, Kutzner H, Cribier B, Schulz T. Benign tumours with follicular differentiation. İn: Pathology and Genetics of Skin Tumours. LeBoit PE, Burg G, Weedon D, Sarasin A, eds. Lyon IARCPress 2006: 152-9.
12. Jaqueti G, Requena L, SanchezYus E: Trichoblastoma is the most common neoplasm developed in nevus sebaceus of Jadassohn: a clinicopathologic study of a series of 155 cases, Am J Dermatopathol 2000; 22: 108-18.

13. Boyd AS. Tumors of the Epidermis. İn: Dermatopathology. Eds, Barnhill RN, Crowson AN,Magro CM, Piepkorn MW. New York The McGraw-Hill Companies, 2010: 556-614.

\section{ABOUT THE AUTHORS}

Article citation: Dilek N, Bedir R, Yüksel D, Ataseven A. A case of basal cell carcinoma secondary to nevus sebaceous. International Journal of Case Reports and Images 2014;5(4):277-280.

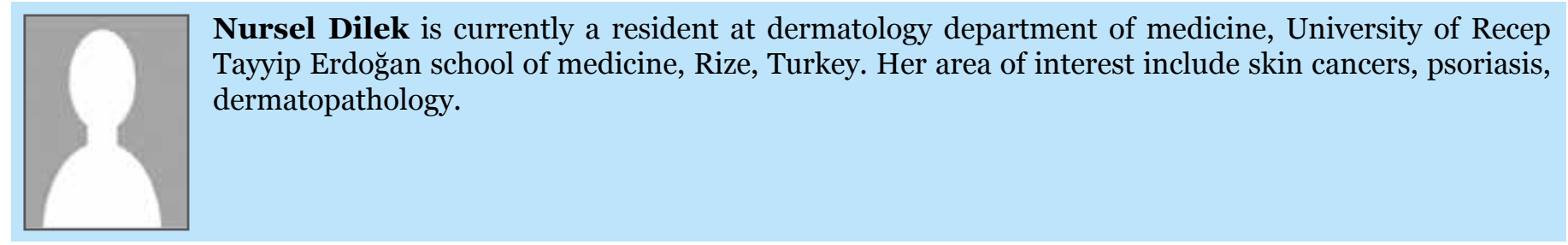

Access full text article on other devices

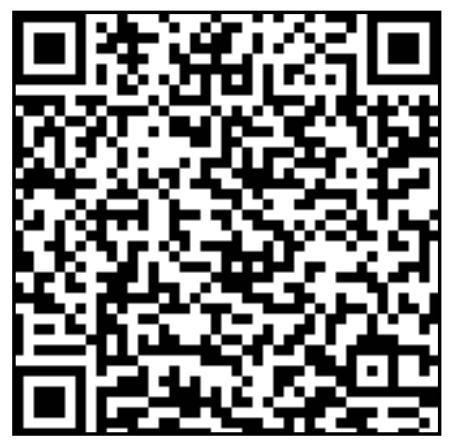

Access PDF of article on other devices

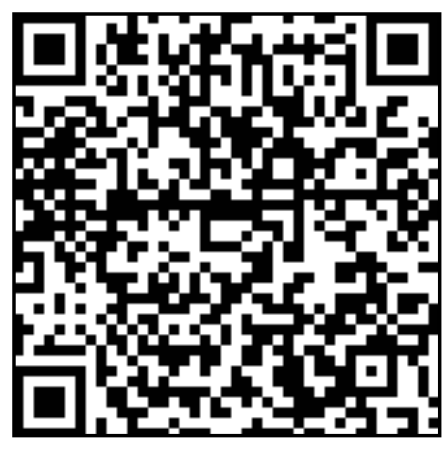

